\title{
ANALISIS PENCAPAIAN KOMPETENSI KOGNITIF DALAM PEMBELAJARAN MUATAN LOKAL BAHASA JAWA MATERI TEMBANG
}

\author{
Nidha Nur Latifah ${ }^{1}$, Filia Prima Artharina ${ }^{2}$, Zainal Arifin ${ }^{3}$ \\ 1,2,3 Jurusan Pendidikan Guru Sekolah Dasar, FIP \\ Universitas PGRI Semarang \\ email : nidhanurl@gmail.com¹,prima123@gmail.com², \\ zainal@gmail ${ }^{3}$
}

\begin{abstract}
Abstrak
Penelitian ini bertujuan untuk mengetahui ketercapaian kompetensi kognitif siswa khususnya dalam pembelajaran bahasa Jawa materi tembang. Ketercapaian kompetensi kognitif menjadi bagian penting dan perlu diperhatikan dalam pembelajaran. Penelitian ini dilakukan di kelas IV SDN Sambiroto 01 Semarang. Penelitian ini menggunakan metode kualitatif. Instrumen penelitian yang digunakan adalah observasi, wawancara, tes tertulis berupa soal isian singkat. Hasil penelitian menunjukan ratarata pencapaian kompetensi kognitif siswa pada pembelajaran tembang secara keseluruhan mencapai $85 \%$ dengan rata-rata pencapaian tertinggi berada pada domain memahami dan rata pencapaian terendah berada pada domain menganalisis. Jadi, dapat disimpulkan bahwa siswa kelas IV SDN Sambiroto 01 memiliki kemampuan kognitif yang baik pada materi tembang.
\end{abstract}

Kata kunci: Bahasa Jawa, Tembang, Kognitif

\section{Abstract}

The purpoose of this study was to determain student achievement of cognitve competence that students, especially in learning Javanese language subject tembang. Achievement of cognitive competence of students becomes an important part and needs to be considered in learning. This research was conducted in class IV SDN Sambiroto 01 Semarang. This study uses a qualitative method. The research instruments used were observation, interviews, written tests in the form of short questions and skills tests. The results showed that the average achievement of cognitive competencies of students in learning as a whole reached $85 \%$ with the highest average achievement in the domain of understanding and the lowest average achievement was in the analyzing domain. So, it can be concluded that fourth grade students of SDN Sambiroto 01 have good cognitive abilities in the tembang material.

Keywords: Javanese, tembang, cognitive 


\section{Pendahuluan}

Pendidikan adalah proses perubahan tingkah laku, penambahan ilmu pengetahuan dan pengalaman hidup agar peserta didik menjadi lebih dewasa dalam pemikiran dan sikap. Pendidikan di era digital saat ini sangatlah pesat, kemajuan dalam bidang teknologi tidak hanya dinikmati oleh orang dewasa saja, anak-anak usia sekolah dasar juga sudah bisa menikmati dari hasil perkembangan teknologi saat ini. Teknologi banyak dimanfaatkan dalam dunia pendidikan, sebagai sarana dan prasarana interaksi antara pendidik dan peserta didik. Perkembangan teknologi saat ini mempunyai dampak positif dan damapak negatif, sebaiknya dampak positif lebih dominan dimanfaatkan oleh pengguna teknologi (Palupi, Dini).

Pendidikan merupakan sebuah sistem. Sebagai sistem, aktivitas pendidikan terbangun dalam beberapa komponen, yaitu pendidik, peserta didik, tujuan pendidikan, alat pendidikan, dan lingkungan pendidikan. Semua komponen yang membangun sistem pendidikan, saling berhubungan, saling tergantung, dan saling menentukan satu sama lain. Setiap komponen memiliki fungsi masing-masing dalam rangka mencapai tujuan pendidikan. Aktivitas pendidikan akan terselenggara dengan baik apabila didukung oleh komponen-komponen dimaksud. Fungsi pendidikan sebenarnya adalah menyediakan fasilitas yang dapat memungkinkan tugas pendidikan dapat berjalan lancar, baik secara struktural, maupun secara institusional. Secara struktural menuntut terwujudnya struktur organisasi yang mengatur jalannya proses kependidikan. Secara institusional mengandung implikasi bahwa proses kependidikan yang terjadi dalam struktur organisasi itu dilembagakan untuk lebih menjamin proses pendidikan itu berjalan secara konsisten dan berkesinambungan mengikuti kebutuhan dan perkembangan manusia yang cenderung ke arah tingkat kemampuan yang optimal (Saat, 2015).

Pasal 1 UU SISDIKNAS no. 20 tahun 2003 disebutkan bahwa Sistem Pendidikan Nasional adalah keseluruhan komponen pendidikan yang saling terkait secara terpadu untuk mencapai tujuan pendidikan nasional. Berangkat dari bunyi pasal ini dapat diketahui bahwa pendidikan adalah sistem yang merupakan suatu totalitas struktur yang terdiri dari komponen yang saling terkait dan secara bersama menuju kepada tercapainya tujuan (Soetarno, 2003: 2). Adapun komponen-komponen dalam pendidikan nasional antara lain adalah lingkungan, sarana-prasarana, sumberdaya, dan masyarakat. Komponen-komponen tersebut bekerja secara bersama-sama, saling terkait dan mendukung dalam mencapai tujuan pendidikan (Munirah, 2015).

Kurikulum 2013 merupakan kebijakan pemerintah di bidang pendidikan dalam rangka menyiapkan generasi yang berkarakter serta siap menghadapi tantangan global. Berdasarkan Permendikbud nomor 67 tahun 2013 tentang Kerangka Dasar dan Struktur Kurikulum SD/MI, Pelaksanaan kurikulum 2013 pada pendidikan dasar, pembelajarannya disajikan menggunakan pendekatan tematik-terpadu. Semua mata pelajaran dipadukan dalam satu tema, namun terdapat beberapa muatan pelajaran yang berdiri sendiri misalnya Pendidikan Agama, Muatan Lokal, PJOK, serta khusus muatan pelajaran Matematika pada kelas tinggi.

Muatan Lokal menjadi salah satu mata pelajaran yang mendukung tercapainya tujuan pelaksanaan kurikulum 2013. Hal tersebut diatur dalam Undang-undang Sistem Pendidikan Nasional Nomor 20 Tahun 2003 Pasal 37 yang menyebutkan bahwa muatan lokal merupakan kegiatan kulikuler yang disesuaikan dengan ciri khas dan potensi lokal masing-masing daerah. Pembelajaran muatan lokal dilaksanakan untuk mengembangkan berbagai keterampilan yang dimiliki peserta didik melalui potensi daerah seperti budaya, bahasa, dan adat istiadat. Suyitno dan Utami (2016: 136) materi tema kurikulum 2013 pada muatan lokal bahasa Jawa Sekolah Dasar disajikan secara implisit dari seluruh kompetensi dasar yang dirumuskan dalam standari isi. Pembelajaran bahasa Jawa telah diatur dalam Peraturan Daerah Provinsi Jawa Tengah Nomor 4 Tahun 2012 yang menyebutkan penyelenggaraan pendidikan menetapkan Bahasa Jawa sebagai mata pelajaran muatan lokal yang diterapkan di Sekolah dengan alokasi waktu 2 jam pelajaran pada setiap kelas (kelas I hingga VI).

Pembelajaran muatan lokal bahasa Jawa bertujuan untuk meningkatkan kemampuan berbahasa peserta didik serta mampu menghargai kebudayaan yang dimiliki.Pembelajaran 
muatan lokal bahasa Jawa sekolah dasar dilihat dari standar isi lebih menekankan pada berbagai materi seperti unggah ungguh basa, kesenian Jawa, aksara Jawa, wayang, dan tokoh kepahlawanan Jawa. Berbagai cakupan materi tersebut perlu diajarkan sejak dini sehingga dapat menciptakan peserta didik sebagai manusia yang berkepribadian dan berkarakter untuk memajukan bangsa sesuai dengan tujuan dari penerapan kurikulum 2013. Hal tersebut sejalan dengan pendapat Ni Wayan Sartini (2009: 29) dimana budaya Jawa penuh dengan simbolsimbol yang mengandung nilai-nilai budaya, etika, moral yang patut dijelaskan kepada generasi selanjutnya.

Pembelajaran muatan lokal bahasa Jawa saat ini dipandang kuno dan kurang terlalu penting, bahkan budaya Jawa kerap dikaitkan dengan hal-hal yang berbau horor membuat siswa kurang berminat mendalami materi yang dipelajari. Keadaan tersebut membuat hasil belajar yang diperoleh siswa tidak maksimal. Hasil belajar yang diperoleh siswa dari proses pembelajaran harus memenuhi beberapa aspek penting. Sani (2016: 120) menekankan hasil belajar siswa pada tiga aspek yaitu aspek kognitif, aspek afektif dan aspek psikomotor. Hal tersebut sejalan dengan penerapan Kurikulum 2013, dimana pembelajaran muatan lokal berfokus pada pengembangan aspek kognitif, aspek afektif, dan aspek psikomotor peserta didik.

Aspek kognitif menjadi aspek penting dalam pembelajaran. Syah dalam Roihah (2009: 3) menyatakan bahwa ranah kognitif adalah sumber sekaligus pengendali ranah-ranah kejiwaan lainnya, yakni afektif (rasa), dan ranah psikomotorik (karsa). Rachmawati dan Daryanto (2015: 40) mengatakan bahwa ranah kognitif yaitu kawasan yang berkaitan dengan aspek intelektual atau berfikir/nalar seperti pengetahuan, pengertian, dan keterampilan berfikir. Aspek kognitif meliputi kemampuan mengingat, memahami, menerapkan, mengalisis, mengevaluasi dan mencipta. Aspek kognitif menjadi acuan tercapainya suatu tujuan pembelajaran.

Ketercapaian atau keberhasilan kemampuan kognitif siswa dapat diketahui melalui hasil belajar. Berdasarkan observasi awal yang peneliti di SDN Sambiroto 01 Semarang, hasil perolehan nilai ulangan harian muatan lokal bahasa jawa dengan ketuntasan minimal 75 , terdapat $62 \%$ siswa yang memenuhi kriteria minimal, sedangkan $38 \%$ siswa masih belum tuntas. Hal tersebut menunjukan masih ada beberapa anak yang belum memenuhi kompetensi yang diharapkan.

Ketidakcapaian kompetensi kognitif beberapa peserta didik terjadi karena adanya kesulitan-kesulitan yang dihadapi, sehingga perlu adanya identifikasi terhadap kesulitankesulitan yang dihadapi untuk menemukan solusi atau penyelesaian agar siswa berhasil mencapai atau memenuhi kemampuan kognitif yang diharapkan. Oleh karena itu dilakukan penelitian terkait "Analisis Pencapaian Kompetensi Kognitif dalam Pembelajaran Muatan Lokal Bahasa Jawa Materi Tembang Kelas IV di SDN Sambiroto 01 Semarang".

\section{Metode}

Metode yang digunakan pada penelitian ini adalah metode kualitatif. Penelitian kualitatif adalah penelitian yang bermaksud untuk memahami fenomena tentang apa yang dialami oleh subjek penelitian misalnya perilaku, persepsi, motivasi, tindakan, dalan lain-lain, secara holistik, dan dengan cara deskripsi dalam bentuk kata-kata dan bahasa, pada suatu kontek khusus yang alamiah dan dengan memanfaatkan berbagai metode alamiah (Moleong, 2011: 6).

Penelitian kualitatif harus mempertimbangkan metodologi kualitatif itu sendiri. Melalui penggunaan metode kualitatif, informasi yang diperoleh menggambarkan dan menguraikan realitas dan situasi yang kompleks sehingga membantu tercapainya tujuan penelitian. Penelitian ini dimaksudkan untuk menguraikan dan mendeskripsikan Pencapaian Kompetensi Kognitif dalam Pembelajaran Muatan Lokal Bahasa Jawa Materi Tembang Kelas IV di SDN Sambiroto 01 Semarang.

Penelitian ini dilaksanakan di SDN Sambiroto 01 Semarang. Penelitian dilakukan pada kelas IV B dan melibatkan seluruh siswa kelas IV B serta guru kelas. Data yang dimaksud dalam penelitian ini yaitu yaitu proses pembelajaran muatan lokal bahasa Jawa materi Tembang dikelas kelas tinggi yaitu kelas 4 , hasil belajar terkait pencapaian kompetensi kognitif 
dalam proses pembelajaran muatan lokal bahasa Jawa serta faktor yang mempengaruhi kesulitan belajar siswa dalam mencapai kompetensi kognitif.

Teknik pengumpulan data pada penelitian ini menggunakan instrumen observasi, wawancara, dokumentasi, dan tes. Tes dalam penelitian ini diberikan kepada setiap siswa secara individu. Tes berupa isian singkat diberikan untuk mendapatkan data serta mengetahui kemampuan kognitif siswa.

Analisis data dilakukan sebelum penelitian di lapangan, saat penelitian di lapangan, sesudah penelitian di lapangan. Miles and Huberman (1984) dalam Sugiyono (2017: 336) mengemukan bahwa aktivitas dalam analisis data kualitatif dilakukan secara interaktif dan berlangsung secara terus menerus sampai tuntas, sehingga datanya sudah jenuh. Aktivitas dalam analisis data, yaitu reduksi data, penyajian data, dan verifikasi data.

\section{Hasil Dan Pembahasan}

Hasil Proses pembelajaran bertujuan agar siswa mencapai kompetensi kognitif telah ditentukan. Kompetensi tersebut diuraikan dalam Standar Kompetensi dan Kompetensi Dasar. Kompetensi dasar tersebut kemudian dikembangkan menjadi indikator yang digunakan sebagai tolak ukur pencapaian kompetensi yang ditentukan.

Ketercapaian kompetensi kognitif dilihat dari hasil belajar yang diperoleh siswa. Hasil belajar siswa didapat dari soal evaluasi atau tes yang diberikan guru dalam proses pembelajaran. Hasil belajar siswa akan menunjukan siswa yang mampu menyelesaikan dengan baik dan siswa yang kurang mampu. Siswa dikatakan sudah mencapai kompetensi kognitif apabila hasil belajarnya sudah sesuai Kompetensi Dasar yang ditetapkan berdasarkan Permendikbud nomor 81A tahun 2013 tentang Implementasi Kurikulum 2013.

Kompetensi Dasar tersebut diuraikan dalam indikator pembelajaran, dimana indikator disesuaikan dengan domain kognitif siswa. Siswa yang mampu mencapai kriteria yang diharapkan sesuai Kompetensi Dasar dan indikator pembelajaran dianggap sudah mencapai kompetensi kognitif, sedangkan siswa yang belum mampu mencapai kriteria yang diharapkan dianggap belum mampu mencapai kompetensi kognitif. Siswa yang sudah mencapai domain kognitif yang diharapkan, sudah tentu mencapai Kriteria Ketuntasan Minimal (KKM) yaitu 75.

Kompetensi kognitif yang harus dicapai siswa disesuaikan dengan Standar Kompetensi dan Kompetensi Dasar berdasarkan Permendikbud nomor 81A tahun 2013 tentang Implementasi Kurikulum 2013. Kompetensi Dasar kelas IV materi Tembang berdasarkan Permendikbud nomor 81A tahun 2013 adalah KD 3.2 yaitu Memahami tembang Gambuh. Kompetensi Dasar tersebut menjadi pedoman dalam mengukur kompetensi kognitif siswa yang dilihat dari hasil belajar dan disesuaikan dengan ketercapaian domain-domain kognitif serta diukur menggunakan KKM yang ditentukan. Domain-domain kognitif terdiri dari mengingat, memahami, menerapkan, menganalisis, mengevaluasi, dan mencipta.

Hasil belajar kognitif siswa didapat dari hasil tes atau mengerjakan soal. Soal yang diberikan kepada siswa disusun oleh guru mata pelajaran atau guru kelas berdasarkan Indikator yang disesuaikan dengan kondisi kognitif siswa kelas IV saat ini. Hasil tersebut menjelaskan guru hanya menfokuskan ketercapaian kompetensi kognitif siswa kelas IV pada empat domain yaitu mengetahui/mengingat, memahami, menerapkan dan menganalisis. Domain mengingat (C1) dan menerapkan (C3) dikatakan cukup baik dan berhasil tercapai, sedangkan siswa masih belum menguasai atau belum mencapai kompetensi kognitif pada domain memahami (C2) dan menganalisis (C4).

Beberapa domain kognitif tersebut digunakan sebagai pedoman dalam menyusun indikator materi tembang. Indikator materi tembang pada domain mengingat (C1) adalah mengetahui lirik tembang Gambuh. Indikator pada domain memahami (C2) yaitu memahami struktur atau susunan tembang Gambuh. Indikator pada domain menganalisis (C4) adalah mengidentifikasi karakteristik tembang Gambuh.

Kondisi kemampuan kognitif siswa kelas IV B SDN Sambiroto 01 dalam pembelajaran bahasa Jawa dapat dilihat melalui hasil belajar khususnya pada materi tembang. Hasil penelitian menunjukan kompetensi kognitif siswa kelas IV B pada domain Mengingat (C1) 
ketercapaian atau penguasaannya mencapai $82 \%$, pada domain Memahami (C2) ketercapaian atau penguasaan siswa mencapai $89 \%$, pada domain dan pada domain Menganalisis (C4) ketercapaian atau penguasaan siswa mencapai $71 \%$. Secara keseluruhan ketercapaian atau penguasaan siswa dari domain kognitif C1, C2 dan C4 mencapai 83\%. Ketercapaian kompetensi kognitif secara spesifik dijabarkan sebagai berikut:

1. Domain Mengingat $(\mathrm{C} 1)$

Domain mengingat pada pembelajaran bahasa jawa menuntut siswa mengenali kembali materi atau konsep yang diketahuinya. Domain mengingat terdiri dari dua proses kognitif yaitu mengenali dan mengingat. Domain mengingat pada pembelajaran tembang dijabarkan melalui perintah kepada siswa untuk mengingat atau mengenali lirik/syair tembang Gambuh yang sudah diketahuinya.

Rata-rata pencapaian kompetensi kognitif pada domain ini yaitu $82 \%$. Tingkat pencapaian yang tinggi menandakan bahwa sebagian besar siswa kelas IV kemampuan taraf berpikirnya sudah sampai tahap mengingat (C1). Hal tersebut sejalan dengan pendapat guru kelas IV, dimana kemampuan kognitif siswa dalam pembelajaran bahasa Jawa sudah mencapai domain mengingat. Hal tersebut menandakan siswa sudah mampu mengingat materi yang diajarkan guru terkait tembang Gambuh.

\section{Domain Memahami (C2)}

Domain memahami pada pembelajaran bahasa jawa menuntut siswa memahami, mengerti dan menyatakan kembali materi yang sudah didapatkan dalam proses pembelajaran. Domain memahami pada pembelajaran tembang dijabarkan melalui pertanyaan terkait struktur dan karakteristik tembang Gambuh. Rata-rata pencapaian kompetensi kognitif pada domain memahami adalah $89 \%$. Pencapaian rata-rata yang tinggi menandakan kompetensi kognitif siswa sudah mencapai tahap domain memahami (C2). Hal tersebut berbeda dengan kondisi kemampuan kognitif siswa yang dipaparkan guru kelas IV, dimana siswa dalam pembelajaran bahasa Jawa hanya berada pada domain mengingat dan menerapkan. Kondisi kemampuan kognitif pada domain memahami siswa masih kurang atau belum tercapai.

Kondisi yang dijelaskan ibu Yuda tersebut berbeda dengan hasil belajar yang muncul pada domain memahami khususnya pada materi Tembang. Hasil belajar menunjukan pencapaian rata-rata domain memahami lebih tinggi dibandingkan dengan domain kognitif yang lain. Hal tersebut menandakan siswa sudah mengerti akan suatu konsep, rumus faktafakta untuk kemudian menafsirkan dan menyatakannya kembali.

3. Domain Menganalisis (C4)

Domain menganalisis pada pembelajaran bahasa jawa menuntut siswa menganalisis materi yang sudah diketahuinya dalam proses pembelajaran. Domain menerapkan pada pembelajaran tembang dijabarkan melalui pertanyaan terkait identifikasi makna atau arti dari tembang Gambuh. Hampir sebagian siswa mampu mengidentifikasi makna atau arti dari tembang Gambuh. Hal tersebut dilihat dari tingkat pencapaian kompetensi kognitif pada domain ini yaitu $71 \%$.

Pencapaian rata-rata yang tinggi menandakan sebagian siswa mampu mengerjakan soal yang berkaitan dengan domain Menganalisis (C4) memperoleh suatu pemahaman atas konsep atau materi walaupun masih banyak pula siswa yang belum mencapai kompetensi ini. Hal ini sejalan dengan paparan guru kelas IV dimana kondisi kemampuan kognitif siswa hanya berada pada domain mengingat dan menerapkan, belum mencapai domain menganalisis sehingga masih terdapat banyak siswa yang mendapat skor kurang maksimal pada domain ini.

Ketercapaian kompetensi kognitif yang dijabarkan melalui 3 domain dari tingkatan paling rendah hingga tingkatan yang lebih tinggi ( $C 1, C 2$ dan $C 4)$ yaitu domain mengingat, memahami, dan menganalisis menghasilkan gambaran grafik sebagai berikut : 


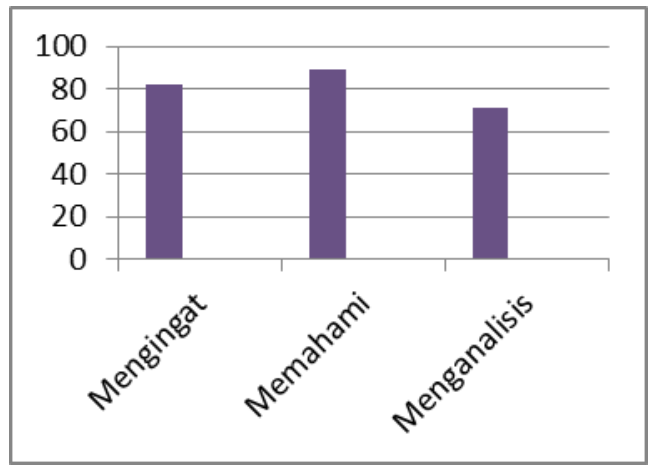

\section{Gambar 1 Grafik Ketercapaian Kompetensi Kognitif C1, C2 dan C4}

Tingginya capaian rata-rata kompetensi kognitif tersebut tercapai karena penyusunan indikator pembelajaran yang menyesuaikan kondisi kemampuan kognitif siswa. Hal tersebut diperkuat dengan teori kognitif Piaget dalam Siregar dan Nara (2011: 33), proses belajar harus disesuaikan dengan tahap perkembangan kognitif yang dilalui siswa. Proses belajar yang dialami seorang anak berbeda pada tahap yang satu dengan tahap yang lainnya.

Berdasarkan hasil penelitian, kompetensi kognitif siswa dalam pembelajaran tembang Gambuh sudah disesuaikan dengan perkembangan kognitif siswa. Penyusunan indikator dilakukan dari domain yang rendah menuju domain yang lebih tinggi. Hal tersebut membuat siswa dapat mencapai kompetensi secara maksimal, sebagaimana terlihat pada tabel dimana pencapaian kognitif siswa secara keseluruhan mencapai $83 \%$.

Hasil penelitian menunjukan 11 siswa belum mencapai kompetensi kognitif yang meliputi domain mengetahui, domain memahami, dan domain menganalisis. Dilihat dari proses pembelajaran siswa yang belum mencapai kompetensi kognitif disebabkan karena antusiasme dan perhatian siswa yang kurang terhadap bahasa Jawa serta penggunaan komponen pembelajaran yang kurang maksimal sebagaimana berdasarkan hasil observasi pembelajaran bahasa Jawa di Kelas IV hanya memanfaatkan buku pegangan sebagai sumber belajar serta menggunakan metode ceramah dan tanya jawab dalam aktivitas penyampaian materi.

Observasi dan wawancara dalam penelitian juga dilakukan untuk mengetahui aktivitas siswa pada pembelajaran bahasa Jawa. Berdasarkan tabel 4.1 yang merupakan hasil observasi pembelajaran bahasa Jawa, diketahui bahwa beberapa siswa terlihat antusias terhadap pembelajaran bahasa Jawa dilihat dari bagaimana mereka mempersiapkan diri sebelum pembelajaran dimulai. Akan tetapi masih terdapat beberapa siswa yang terlihat kurang antusias dalam pembelajaran Bahasa Jawa. Hal tersebut dilihat ketika pembelajaran berlangsung masih banyak siswa yang belum fokus dan melakukan aktivitas lain.

Antusiasme dan perhatian beberapa siswa yang masih kurang, diatasi guru dengan melakukan beberapa kegiatan sebagai berikut:

1. Mengajak siswa menyanyikan tembang anak disertai gerakan yang lucu di awal pembelajaran. Kegiatan tersebut mampu meningkatkan perhatian dan kesiapan siswa untuk melaksanakan pembelajaran bahasa Jawa khususnya materi tembang.

2. Pengondisian kelas yang dilakukan melalui pemberian aktivitas tertentu kepada siswa seperti membaca nyaring secara bersama-sama materi terkait struktur tembang Gambuh yang terdapat pada buku pegangan bahasa Jawa, kemudian memberikan kesempatan kepada siswa untuk menuliskan kata-kata sulit yang ditemukan dalam lirik tembang Gambuh di papan tulis serta tanya jawab spontan yang dilakukan saat proses penyampaian materi berlangsung.

Beberapa aktivitas yang dilaksanakan untuk meningkatkan antusiasme dan perhatian siswa dalam pembelajaran seperti yang terdapat pada Rachmawati dan Daryanto (2015: 38), dimana pembelajaran merupakan proses interaksi peserta didik dengan pendidik dan sumber belajar pada suatu lingkungan belajar. Interaksi siswa dengan guru, interaksi siswa dengan teman dan interaksi siswa dengan sumber belajar memunculkan adanya aktivitas belajar pada 
siswa tersebut. Meski demikian, aktivitas atau kegiatan tersebut belum optimal dikarenakan sumber belajar yang masih terbatas pada buku pegangan saja dan penyampaian materi yang dilakukan melalui metode ceramah dan tanya jawab, belum digunakannya metode atau model pembelajaran yang lebih bervariasi.

Penggunaan metode atau model dalam pembelajaran sangat penting untuk menunjang ketercapaian dari tujuan pembelajaran. Sebagaimana dijelaskan Joyce dalam Trianto (2011: 5) bahwa setiap model pembelajaran mengarahkan kita ke dalam mendesain pembelajaran untuk membantu peserta didik sedemikian rupa sehingga tujuan pembelajaran dapat tercapai. Model pembelajaran membantu pelaksanaan pembelajaran sehingga materi yang disampaikan dapat diterima siswa dengan tepat.

Variasi metode dan model pembelajaran yang tepat dalam pembelajaran bahasa Jawa materi tembang dapat menjadikan kegiatan belajar siswa lebih bermakna. Hal tersebut membuat siswa belum mendapatkan kebermaknaan materi pembelajaran secara potensial sehingga siswa belum dapat mencapai kompetensi kognitif. Sebagaimana dalam teori belajar bermakna yang dikemukakan oleh Ausubel dalam Rifa'i Catharina (2016: 164) dijelaskan bahwa belajar bermakna adalah proses mengaitkan informasi baru dengan konsep-konsep yang relevan dan terdapat dalam struktur kognitif seseorang. Pembelajaran bermakna perlu diterapkan untuk meningkatkan kemampuan kognitif siswa dengan aktivitas pemberian informasi yang kemudian diasosiasikan dengan konsep dalam struktur kognitif tersebut.

\section{Simpulan dan Saran}

Hasil ketercapaian kompetensi kognitif pada materi tembang secara keseluruhan mencapai $83 \%$. Secara spesifik pada domain mengingat $(\mathrm{C} 1)$ ketercapaian kompetensi kognitif mencapai $82 \%$, pada domain memahami (C2) ketercapaian kompetensi kognitif mencapai $89 \%$, dan pada domain menganalisis (C4) ketercapaian kompetensi kognitif mencapai71\%.

Berdasarkan kesimpulan penelitian ini maka adapun saran yang dapat disampaikan oleh peneliti antara lain: 1) Bagi Guru, proses pembelajaran perlu dilaksanakan secara lebih bermakna lagi dan menggunakan metode pembelajaran yang lebih menarik perhatian siswa, 2) Bagi Siswa, hendaknya lebih meningkatkan rasa cintanya terhadap bahasa Jawa serta meningkatkan motivasi dan perhatiannya dalam pembelajaran bahasa Jawa, dan 3) Bagi Orang Tua, hendaknya ikut mendukung pelaksanaan pembelajaran bahasa Jawa dengan melakukan pembiasaan berbicara menggunakan bahasa Jawa ketika di rumah.

\section{Daftar Rujukan}

Moleong, lexy J. 2011. Metodologi Penelitian Kualitatif. Bandung: PT Remaja Rosdakarya.

Munirah. 2015. Sistem Pendidikan Di Indonesia: Antara Keinginan Dan Realita . Jurnal Auladuna, Vol. 2 No. 2 Desember 2015: 233-245

Rachmawati, Tutik, dan Daryanto. 2015. Teori Belajar dan Proses Pembelajaran yang Mendidik. Jakarta: Gava Media.

Rifa'i, Achmad RC dan Tri Catharina Anni. 2016. Psikologi Pendidikan. Semarang: UNNES PRESS.

Roihah, Imalatur. 2009. Implikasi Teori Jean Piaget dalam Pembentukan Kepribadian Muslim Pada Anak Usia Sekolah 7-12 Tahun. Skripsi. UIN Sunan Kalijaga Yogyakarta.

Sani, Abdul Ridwan. 2016. Penilaian Autentik. Jakarta. PT Bumi AKSARA. 
Siregar, Eveline dan Nara, Hartini. 2014. Teori Belajar dan Pembelajaran. Bogor: Ghalia Indonesia.

Sugiyono. 2017. Metode Penelitian Pendidikan. Bandung: PT Alfabet.

Suyitno, Utmai H.R. 2016. Relevansi Tema Kurikulum 2013 Sekolah Dasar Muatan LokalNasional. Malih Peddas. Vol. 6 No. 2.

Saat, Sulaiman. 2015. Faktor-Faktor Determinan Dalam Pendidikan (Studi Tentang Makna Dan Kedudukannya Dalam Pendidikan) . Jurnal Al-Ta'dib Vol. 8 No. 2, Juli-Desember 2015

Palupi, Dini. 2018. Pendidikan Karakter Pada Anak Sekolah Dasar di Era Digital . Jurnal Pendidikan Dasar vol. 2, no. 1, 2018 STAIN Curup - Bengkulu| p ISSN 2580-362X; e ISSN 2580-3611 http://journal.staincurup.ac.id/index.php/JPD

Trianto. 2011. Model-Model Pembelajaran Inovatif Berorientasi Konstruktivistik. Jakarta: Prestasi Pustaka.

Wayan, Ni Sartini. 2009. Menggali Nilai Kearifan Lokal Budaya Jawa Ungkapan (Bebasan, Saloka, dan Paribasa). Jurnal IImiah Bahasa dan Sastra. Vol V. No. 1. 